\title{
Effect of organosulfur compounds on the expression of UDP-glucuronosyltransferase and thyroid hormone level in TCDD-treated rats
}

\author{
Young-Sook Hong and Hyung-Lae Kim \\ 1 Department of Biochemistry, Division of Cancer Research, \\ Medical Research Center, Medical College, Ewha Womans University, \\ Seoul 158-056, Korea \\ 2 Corresponding author \\ Accepted 5 September 1997
}

Abbreviations : UGT, UDP-glucuronosyltransferase; TCDD, 2,3,7,8-tetrachlorodibenzop-dioxin; DAS, diallyl sulfide; DADS, diallyl disulfide

\section{Introduction}

The ubiquitous existance of polychlorinated dibenzo- $p$ dioxins and polychlorinated dibenzofurans in the environment and their accidental exposure have raised concerns about the possible threat to human health. The potent isomer 2,3,7,8-tetrachloro-dibenzo- $p$-dioxin (TCDD) is a multi-site carcinogen in rodents and is classified as a tumor promoter in liver and extrahepatic tissues. TCDD increases tumor incidences in the lung, nasal turbinates/ hard palate, adrenal cortex, and thyroid tumors in rodents (Huff et al., 1991). In particular, the incidence of thyroid tumors in rodents is comparable to or greater than that of liver tumors at equivalent doses (National Toxicology Program, 1982). It is generally believed that TCDD produces its effects by altering gene expression in target cells.

The hepatic microsomal UDP-glucuronosyltransferases (UGTs), a major family of phase II drug-metabolizing enzymes, catalyze the transfer of the glucuronic acid moiety from UDP-glucuronic acid to numerous chemicals containing hydroxyl, carboxyl, amino, imino, or sulfhydryl group (Tephly and Burchell, 1990). Elimination of many hydrophobic xenobiotics and/or metabolites is facilitated by their conjugation with hydrophilic UDP-glucuronic acid, catalyzed by a family of enzymes known as UGTs (Burchell and Coughtrie, 1989). Thus, UGTs may play an important cytoprotective role, either by preventing the accumulation of potentially toxic xenobiotics or metabolites or by avoiding their subsequent bioactivation (Muller et al., 1990). The UGTs are divided into two gene families, termed UGT1 and UGT2, based upon a cDNA sequence comparison. The UGT1 family consists of several isozymes with differing amino-terminal domains and an identical carboxyl-terminal domain. The variable amino-terminal portions of UGT1 proteins are thought to be responsible for the aglycone specificity of the isozymes. In rats, UGT enzymes have been tentatively divided into two subfamilies based upon similarities in amino acid sequences of the variable regions (UGT1A and UGT1B). The isozyme UGT1A, which contains the amino-terminal portion encoded by the first exon of $1 \mathrm{~A}$, has been identified as a 4-nitrophenol UGT (Emi et al., 1995).

Thyroid hormone plays a very important role in brain development (Porterfield and Hendrich, 1993), especially during the early postnatal period (Davenport et al, 1976). The presence of adequate circulation of $\mathrm{T}_{4}$ concentration is especially critical for normal brain development, because $\mathrm{T}_{3}$ does not cross the blood brain barrier (Ruiz et al., 1988; 
Calvo et al., 1990). The induction of hepatic UGT1 by TCDD and other chlorinated hydrocarbones increases thyroxine glucuronidation (Henry Gasiewicz, 1987; Van Birgelen et al., 1993; Lans et al., 1993) and biliary excretion of $\mathrm{T}_{4}$-glucuronide resulting in decreased levels of circulating $T_{4}$ (Van Birgelen et al., 1994). Although the mechanism by which TCDD induces thyroid tumors in rodents has not been clearly established, studies with other inducers of hepatic microsomal enzymes support the tentative finding that elevated levels of thyroidstimulating hormone (TSH) lead to thyroid follicular cell hyperplasia and hypertrophy, and that if stimulation is prolonged, these changes may progress to neoplasia (Hill et al., 1989; McClain et al., 1989).

The current study is motivated by the hypothesis that the identification and exploitation of dietary anticarcinogens may substantially contribute to the prevention of tumor formation. Organosulfur compounds present in garlic and onions, such as allyl sulfide (DAS), allyl disulfide (DADS), and allyl methyl di- and trisulfide, and garlic and onion oil have been found to inhibit carcinogenesis in several organs (Belman, 1983; Wargovich et al., 1987; Sparnins et al., 1988; Wattenberg et al., 1989; Takahashi et al., 1992). Inhibition of the P450 enzymes responsible for the metabolic activation of the carcinogenic and toxic chemicals is believed to be a major mechanism of the observed chemopreventive effect of DAS (Takada et al., 1994; Burchell et al., 1995; Hong, 1997). Several organosulfur compounds inhibit carcinogenesis by increasing the metabolism, detoxification, and elimination of carcinogen through phase I and phase II enzymes (Talalay, 1992; Wattenberg, 1992). This study was designed to examine the effect of TCDD on the thyroid hormone level and UGT1 gene expression. Furthermore, we examined the protective effects of DAS, garlic extract, or DADS on TCDD-induced changes.

\section{Materials and Methods}

\section{Chemicals}

$\left[\alpha^{32} \mathrm{P}\right] \mathrm{dCTP}(3,000 \mathrm{Ci} / \mathrm{mmol})$ was obtained from Amersham (Buckinghamshire, UK). TCDD was perchased from AccuStandard (New Haven, USA). Diallyl sulfide and diallyl disulfide were purchased from Aldrich (Milwaukee, USA). Garlic extract was kindly provided by Bolak Co. (Hwasung-kun. Korea). All other chemicals were obtained from Sigma Chemical (St. Louis, MO, USA).

\section{Treatment of animals and analysis thyroid hormones}

Male and female Sprague-Dawley rats weighing 180-200 g were maintained on the standard laboratory chow under the controlled temperature with 12-h light and dark cycles. After an acclimation period of 1 week, the rats were given
TCDD (10 $\mu \mathrm{g} / \mathrm{kg}$ body weight, in corn oil) to the experimental group and corn oil ( $5 \mathrm{ml} / \mathrm{kg}$ body weight) to the control by oral gavage. After 4 days, DAS $(200 \mathrm{mg} / \mathrm{kg}$ body weight in corn oil), garlic extract $(200 \mathrm{mg} / \mathrm{kg}$ body weight in distilled water) or DADS(50 mg/kg body weight in corn oil) was administered orally. At $18 \mathrm{~h}$ after the last treatment, the rats were lightly anesthetized with ether and $1.5 \mathrm{ml}$ of blood was drawn from heart with a 22-gauge needle and $0.5 \mathrm{ml}$ syringe. The plasma was separated by centrifugation and stored at $-70^{\circ} \mathrm{C}$ prior to determination of total $\mathrm{T}_{4}$ and $\mathrm{T}_{3}$ levels by radioimmunoassay with kits purchared from Abbott Laboratories (North Chicago, USA).

\section{Preparation of tissue microsomes and determination of UGT1 activity}

After withdrawal of blood, tissues were removed and weighed. Microsomes were prepared by ultracentrifugation $(100,000 \mathrm{~g}$ for $60 \mathrm{~min})$ of the postmitochondrial supernatant $(10,000 \mathrm{~g}$ for $20 \mathrm{~min})$ from a $25 \%(\mathrm{w} / \mathrm{v})$ tissue homogenate as described (Lu and Levin, 1972) and stored at $-70^{\circ} \mathrm{C}$. Protein concentration was determined by the method of Lowry (Lowry et al, 1951). UGT activity toward 4-nitrophenol was measured by the method of Burchell and Weatherill (1981).

\section{RNA isolation and hybridization analysis}

Total RNA was isolated from the liver using a RNA isolation kit (Ultraspec-II RNA, Biotecx Laboratories, Houston, USA). For Northern analysis, electrophoresis was carried out on a $1 \%$ agarose gel containing $2.2 \mathrm{M}$ formaldehyde, and then the RNA was transferred on to a nylon membrane (S\&S) in $20 \times$ SSC and were immobilized by UV irradiation. The membrane was prehybridized in $6 \times$ SSC, $50 \%$ deionized formamide, $10 \times$ Denhardt's solution, $0.5 \%$ SDS, $0.4 \mathrm{mg} / \mathrm{ml}$ denatured herring sperm DNA at $44^{\circ} \mathrm{C}$ for $24 \mathrm{~h}$, and hybridization was performed at $44^{\circ} \mathrm{C}$ for $48 \mathrm{~h}$ using the selective cDNA probe for exon 1 of UGT1A1. The CDNA probes were labeled with $\left[\alpha-{ }^{32} \mathrm{P}\right] \mathrm{dCTP}$ using the random-primed labeling system. The membrane was washed twice in $2 \times$ SSC, $0.1 \%$ SDS at $50^{\circ} \mathrm{C}$ for $20 \mathrm{~min}$. The membrane was exposed for 3 days at $-70^{\circ} \mathrm{C}$ to Kodak XAR- 5 film with intensifying screens. The bands on the autoradiographies were quantified by using Bio-imaging analyzer system (BAS 2500, Fuji Photofilm Co.).

\section{Statistical analysis}

Results were expressed as mean \pm SD. Statistical analyses were performed using the student t-test.

\section{Results}

\section{Thyroid hormone concentration}

The total concentration of plasma $\mathrm{T}_{4}$ is shown in Table 
1. In male rats, the plasma $T_{4}$ concentration was significantly lower for the TCDD-alone animals compared to control group animals (TCDD alone < control). In the TCDD + DAS group and TCDD + garlic extract group, the $\mathrm{T}_{4}$ concentrations were also decreased as much as in the TCDD-alone treated group (TCDD alone = TCDD + DAS; TCDD + garlic extract). However, the concentration for the TCDD + DADS treated animals was higher than for TCDD-alone group (but still lower than in control group animals; TCDD alone < TCDD + DADS < control). In female rats, the $\mathrm{T}_{4}$ concentration for the TCDD-alone group was also significantly lower than control group animals. The concentration for TCDD + DAS, TCDD + garlic extract, and TCDD + DADS groups were all moderatly higher than TCDD alone animals (but lower than control animals; TCDD alone $<$ TCDD + DADS < control). We compared female rats with male rats in respect to their $\mathrm{T}_{4}$ concentration. In both, the TCDD + DAS and TCDD + garlic extract groups, the $\mathrm{T}_{4}$ concentration was higher in female than in male rats.

The total concentration of plasma $T_{3}$ is shown in Table 2. The concentration for TCDD-alone group (male) was also much lower than control animals. The concentration for the TCDD + garlic extract group was higher than for TCDD-alone group, but not as high as control group. The

Table 1. The effect of DAS, garlic extract or DADS on plasma total $T_{4}$ concentration.

\begin{tabular}{lcc}
\hline Group & $\begin{array}{c}\text { Male } \\
(\mu \mathrm{g} / 100 \mathrm{ml} \text { plasma })\end{array}$ & $\begin{array}{c}\text { Female } \\
(\mu \mathrm{g} / 100 \mathrm{ml} \text { plasma })\end{array}$ \\
\hline Control & $4.08 \pm 0.52$ & $3.96 \pm 0.24$ \\
TCDD & $1.27 \pm 0.28^{\mathrm{a}}$ & $0.99 \pm 0.20^{\mathrm{a}}$ \\
TCDD+DAS & $1.24 \pm 0.13^{\mathrm{a}}$ & $2.56 \pm 0.50^{\mathrm{b}, \mathrm{d}}$ \\
TCDD+garlic extract & $1.54 \pm 0.22^{\mathrm{a}}$ & $2.01 \pm 0.16^{\mathrm{a}, \mathrm{c}}$ \\
TCDD+DADS & $2.16 \pm 0.54^{\mathrm{b}}$ & $1.97 \pm 0.47^{\mathrm{a}, \mathrm{e}}$ \\
\hline
\end{tabular}

${ }^{a}$ Significantly different from control value, $P<0.001 ;{ }^{b}$ significantly different from contro value, $P<0.01 ;{ }^{c}$ significantly different from TCDD value, $P<0.001 ;{ }^{d}$ significantly different from TCDD value, $P<0.01$; ${ }^{\text {e }}$ significantly different from TCDD value, $P<0.05$

Table 2. The effect of DAS, garlic extract or DADS on plasma total $T_{3}$ concentration.

\begin{tabular}{lcc}
\hline Group & $\begin{array}{c}\text { Male } \\
(\mathrm{ng} / 100 \mathrm{ml} \text { plasma })\end{array}$ & $\begin{array}{c}\text { Female } \\
(\mathrm{ng} / 100 \mathrm{ml} \text { plasma })\end{array}$ \\
\hline Control & $84.50 \pm 4.07$ & $58.84 \pm 5.48$ \\
TCDD & $64.95 \pm 3.55^{\mathrm{b}}$ & $54.12 \pm 2.34$ \\
TCDD+DAS & $47.28 \pm 5.32^{\mathrm{a}, \mathrm{d}}$ & $63.99 \pm 1.15^{\mathrm{a}}$ \\
TCDD+garlic extract & $70.18 \pm 3.49^{\mathrm{b}}$ & $76.69 \pm 5.93^{\mathrm{b}, \mathrm{c}}$ \\
TCDD+DADS & $59.86 \pm 4.03^{\mathrm{a}}$ & $62.03 \pm 7.23$ \\
\hline
\end{tabular}

${ }^{a}$ Significantly different from control value, $P<0.001 ;{ }^{b}$ significantly different from control value, $P<0.01 ;{ }^{\circ}$ significantly different from TCDD value, $P<0.01 ;{ }^{d}$ significantly different from TCDD value, $P<0.05$
$\mathrm{T}_{3}$ concentration in female rats was reduced only for TCDD-alone treated group. The TCDD + DAS, TCDD + garlic extract, and TCDD + DADS groups showed much higher $\mathrm{T}_{3}$ concentration than TCDD-alone as well as the control group.

\section{4-Nitrophenol UGT1 activity and expression}

4-Nitrophenol UGT1 activity is shown in Table 3 and Table 4. In male rat liver microsomes, 4-nitrophenol UGT1 activity was significantly increased for the TCDD alone group. Furthermore, the TCDD + DAS group shows higher activity than does the TCDD-alone group. The activity for TCDD + garlic extract and TCDD + DADS groups were similar to TCDD-alone group. In male rat lung microsomes, the activity was also increased, but the amount of increased activity was smaller than in liver microsomes. In female rats, the UGT activity in liver microsomes was much higher than in control group. The activity for TCDD + DAS, TCDD + garlic extract, and TCDD + DADS groups were higher than in TCDD-alone group.

4-Nitrophenol UGT1 gene expression is shown in Figures 1 and 2. We measured UGT1 gene expression in rat liver RNA after treatment. In male rat liver RNA, UGT1 expression was relatively high for the TCDD +

Table 3. The effect of DAS, garlic extract or DADS on 4-Nitrophenol UDPglucuronosyltransferase activity in TCDD treated male rat liver, lung microsomes.

\begin{tabular}{lcc}
\hline Group & $\begin{array}{c}\text { Liver } \\
(\mathrm{nmol} / \mathrm{mg} \text { protein/min})\end{array}$ & $\begin{array}{c}\text { Lung } \\
(\mathrm{nmol} / \mathrm{mg} \text { protein/min})\end{array}$ \\
\hline Control & $8.81 \pm 0.467$ & $2.17 \pm 0.384$ \\
TCDD & $22.51 \pm 0.654^{\mathrm{a}}$ & $3.67 \pm 0.120^{\mathrm{a}}$ \\
TCDD+DAS & $31.88 \pm 1.447^{\mathrm{a}, \mathrm{b}}$ & $6.64 \pm 0.150^{\mathrm{a}, \mathrm{c}}$ \\
TCDD+garlic extract & $19.22 \pm 2.028^{\mathrm{a}, \mathrm{c}}$ & $2.81 \pm 0.322$ \\
TCDD+DADS & $21.28 \pm 0.788^{\mathrm{a}}$ & $3.92 \pm 0.455^{\mathrm{a}}$ \\
\hline
\end{tabular}

a Significantly different from control value, $P<0.001 ;{ }^{b}$ significantly different from control value, $P<0.01 ;{ }^{c}$ significantly different from TCDD value, $P<0.01 ;{ }^{d}$ significantly different from TCDD value, $P<0.05$

Table 4. The effect of DAS, garlic extract or DADS on 4-Nitrophenol UDPglucuronosyltransferase activity in TCDD treated female rat liver, lung microsomes.

\begin{tabular}{lcc}
\hline Group & $\begin{array}{c}\text { Liver } \\
(\mathrm{nmol} / \mathrm{mg} \text { protein/min) }\end{array}$ & $\begin{array}{c}\text { Lung } \\
(\mathrm{nmol} / \mathrm{mg} \text { protein/min})\end{array}$ \\
\hline Control & $8.15 \pm 0.289$ & $2.52 \pm 0.370$ \\
TCDD & $24.18 \pm 0.404^{\mathrm{a}}$ & $4.83 \pm 0.020^{\mathrm{b}}$ \\
TCDD+DAS & $25.87 \pm 0.186^{\mathrm{a}, \mathrm{c}}$ & $5.18 \pm 0.315^{\mathrm{b}}$ \\
TCDD+garlic extract & $26.02 \pm 0.092^{\mathrm{a}, \mathrm{c}}$ & $4.35 \pm 0.045^{\mathrm{b}, \mathrm{d}}$ \\
TCDD+DADS & $27.41 \pm 0.812^{\mathrm{a}, \mathrm{c}}$ & $6.15 \pm 0.785^{\mathrm{b}}$ \\
\hline
\end{tabular}

${ }^{a}$ Significantly different from control value, $P<0.001$; ${ }^{b}$ significantly different from control value, $P<0.01 ;{ }^{c}$ significantly different from TCDD value, $P<0.01$; ${ }^{d}$ significantly different from TCDD value, $P<0.05$. 


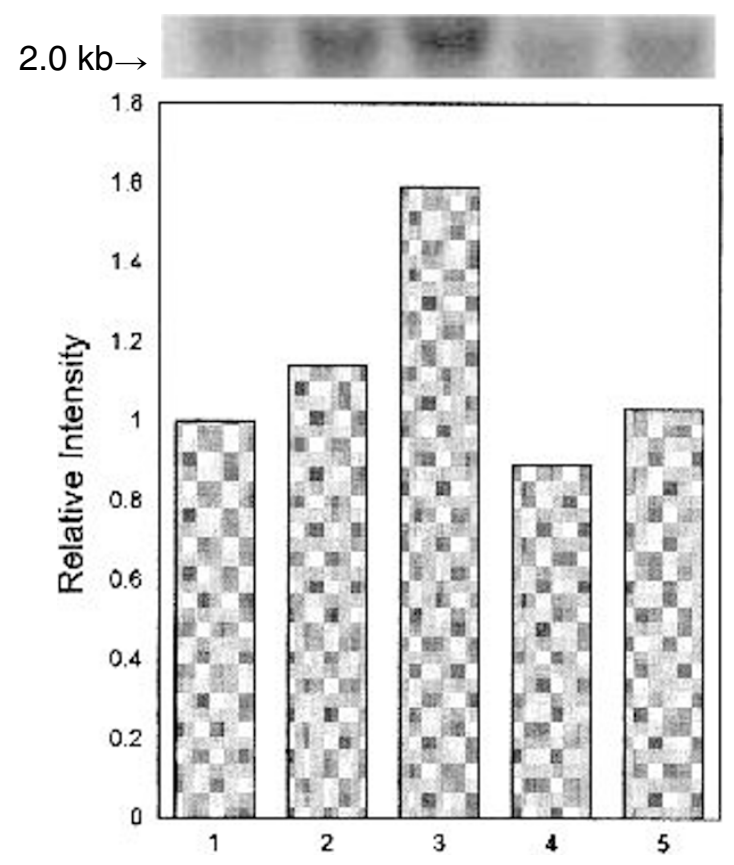

Figure 1 Northern blot analysis for expression of UGT1 mRNA. RNA was extracted from liver tissues from TCDD and TCDD + DAS, garlic extract, DADS treated male rat. RNA $(20 \mu \mathrm{g})$ was separated in a $1 \%$ agarose/2.2M formaldehyde gel, transferred to nylon membrane and hybridized with ${ }^{32} \mathrm{P}$-labeled CDNA. Lane 1, corn oil; lane 2, TCDD; lane 3, TCDD + DAS; lane 4, TCDD + garlic extract; lane 5, TCDD + DADS.

DAS group.

\section{Discussion}

Several hepatic microsomal enzyme inductions have been shown to induce alterations in thyroid hormone levels and thyroid gland function. Microsomal enzyme inducers such as TCDD and polychlorinated and polybrominated biphenyl have been shown to reduce circulating thyroid hormone levels (Allen-Rowlands, 1981; Gorski and Rozman, 1997). This reduction of thyroid hormone levels can lead to a stimulation of the thyroid gland by thyroid-stimulating hormone (TSH) through the normal thyroid feedback loop. It has been postulated that thyroid tumor promotion produced by TCDD is not due to a direct effect on the thyroid gland, but rather due to an alteration of the degradation and elimination of thyroid hormones, leading to a stimulation of the thyroid by TSH (McClain et al., 1989). Chronic administration of many microsomal enzyme inducers has been shown to produce thyroid hypertrophy and hyperplasia (Hill et al., 1989).

Thyroid hormones are degraded predominantly in the liver and excreted in bile. A major pathway of thyroid hormone biotransformation is glucuronidation of thyroxine $\left(T_{4}\right)$. The microsomal enzyme, UGT catalyzes the forma-

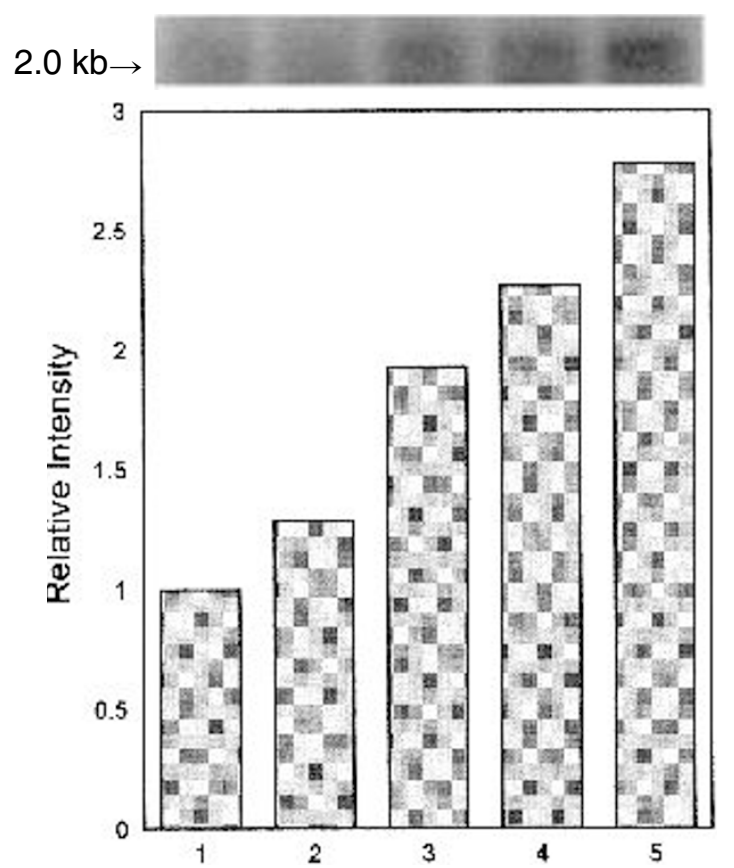

Figure 2. Northern blot analysis for expression of UGT1 mRNA. RNA was extracted from liver tissues from TCDD and TCDD + DAS, garlic extract, DADS treated female rat. RNA $(20 \mu \mathrm{g})$ was separated in a $1 \%$ agarose/2.2M formaldehyde gel, transferred to nylon membrane and hybridized with ${ }^{32} \mathrm{P}$-labeled cDNA. Lane 1, corn oil; lane 2, TCDD; lane 3, TCDD + DAS; lane 4, TCDD + garlic extract; lane 5, TCDD + DADS.

tion of $\mathrm{T}_{4}$-glucuronide, which is subsequently excreted into bile. The UGTs consist of a family of related enzymes that differ in their substrate specificities and their ability to be induced upon treatment with various chemicals. UGTs are involved in the elimination of thyroxine as $\mathrm{T}_{4}$ glucuronides, the main pathway for metabolic inactivation of $\mathrm{T}_{4}$ in rats. Moreover, good correlations have been found between decreased plasma thyroid hormone concentrations and induction of $\mathrm{T}_{4}$-UGT by 3-methyl-cholanthrene, TCDD and 2,3,3',4,4',5-hexachlorobiphenyl (Van Birgelen et al., 1993). Visser et al. (1993) reported that UGT1 (phenol UGT) is involved in the glucuronidation of $\mathrm{T}_{4}$.

It is therefore possible that an increase in the glucuronidation of $T_{4}$ is responsible for the observed reduction of plasma levels of UGT activity after treatment with TCDD, TCDD + DAS and TCDD + garlic extract (see Results).

We have analyzed the inducibility of UGT1 gene by TCDD, TCDD + DAS, garlic extract and DADS in rat liver and lung. DAS prevented $\mathrm{N}$-nitrosomethylbenzylamineinduced esophageal tumor formation (Wargovich et al., $1992)$, benzo( $\alpha)$ pyrene induced forestomach neoplasia (Sparnins et al., 1988), and dimethylhydrazine-induced colonic adenocarcinoma (Wargovichl., 1987) when given by intragastric intubation prior to carcinogen challenge. DADS also prevented $N$-nitrosodiethylamine-induced forestomach neoplasia when given prior to the carcinogen 
(Wattenberg et al., 1989).

The modulation of metabolism of carcinogen by DAS or DADS was considered as one possible mechanism for the protection against cancer by several author (Wargovich, 1987; Sparnins et al., 1988; Reddy et al.,1993). Several studies showed that allyl sulfides can modulate hepatic drug-metabolizing enzymes. This study showed that administration of TCDD + DAS, garlic extract or DADS produces different effects in rat liver and lung. The difference in the metabolism of DAS and DADS could also account for their different protective properties on the initiation phase of chemically-induced cancers. It seems that the chemopreventive effects of allyl sulfides on chemical-induced carcinogenesis depend on the compound, the carcinogen, and the organ site investigated.

Both allyl sulfides modified the same parameters in liver and lung. Both allyl sulfides increased phase II enzymes, UGT. The present results, together with previous results from several laboratories, suggest that alteration of thyroid function may be secondary inducible expression gene of UGT1. Thus, microsomal enzyme inducers may reduce thyroid hormone levels by an extrathyroidal mechanism, and their actions may be more complex than previously assumed.

Based on our finding that UGT1 expression and sensitivity for cancer was variable in presence of DAS, garlic extract, DADS according to treated animal gender and tissue (see Results), we conclude that UGT1 gene expression by DAS and garlic extract may contribute to individual variations in cancer suceptibility. By modifying UGT1 expression, DAS and garlic extract may modulate the ability of UGT1 to detoxify carcinogens.

\section{Acknowledgement}

This work was supported by the Ewha Research Grant of Ewha Womans University

\section{References}

Allen-Rowlands, C. F., Castracane, V. D., Hamilton, M. G. and Seiter, J. (1981) Effect of polymorphism biphenyls (PBB)on the pituitary-thyroid axis of the rat. Proc. Soc. Exp. Biol. Med. 166: 506-514

Belman, S. (1983) Onion and garlic oils inhibit the tumor promotions. Carcinogenesis 4 1063-1065

Burchell, B. and Weatherill. P (1981) 4-Nitrophenol UDP-glucuronyltrans-ferase (rat liver). Methods Enzymol. 77: 169-193

Burchell. B., Brierley. C.H. and Rance, D. (1995) Specificity of human UDPglucuronosyltransferase and xenobiotic glucuronidation. Life Sci. 57: 1819-1831

Burchell., B. and Coughtrie., W. H. (1989) UDP-glucuronosyltransferase. Pharmacol. Ther. 43: 261-289

Calvo, R., Obregon, M. J., Ruiz de Ona, C., Escobar del Rey, F. and Morreale de Escobar, G. (1990) Congenital hypothyroidism, as studied in rats. J. Clin. Invest. 86: 889-899.
Davenport, J. W., Gonzalez, L. M., Hennies, R. S. and Hagguist, W. W. (1976) Severity and timing of early thyroid deficiency as factors in the induction of learning disorders in rats. Hor. Behav. 7: 139-158

Emi. Y., Ikushiro. S.-I. and T. Iyanagi. (1995) Drug-responsive and tissue-specific alternative expression of multiple first exon in rat UDP-glucuro-nosyltransferase family1 (UGT 1) gene complex. J. Biochem. 117: 392-399

Gorski, J. R., and Rozman, K. (1997) Dose response and time course of hypothyroxinemia and hypoinsulinemia and chacterization of insulin hypersensitivity in 2,3,7,8-tetrachlorodibenzo-p-dioxin (TCDD)-treated rats. Toxicology 44: 297-307

Henry. E. C. and Gasiewicz, T. A (1987) Changes in thyroid hormones and thyroxine glucuronidation in hamsters compared with rats following treatment with 2,3,7,8tetrachlorodibenzo-p-dioxin. Toxicol. Appl. Pharmacol. 89: 165-174.

Hill, R. N., Erdreich, L. S., Paynter, O. E., Roberts, P. A., Rosenthal, S. L. and Wilkinson, C. F. (1989) Thyroid follicular cell carcinogenesis. Fund. Appl. Toxicol. 12: 629-697

Hong Y. S. (1997) Effect of diallyl sulfide on TCDD-induction cytochrome P-450 1A1 gene in mouse lung. Biochem. Arch. 13: 179-187

Huff, J. E., Salmon, A. G., Hooper, N. K. and Zeise, L. (1991) Long-term carcinogenesis studies on 2,3,7,8-tetrachlorodibenzo-p-dioxin and hexa-chlorodibenzo-p-dioxins. Cell Biol. Toxicol. $7: 67-94$

Lans, M. C., Brouwer, I., de Winden, P. and Vrouwer, A. (1993) Different effects of 2,3,7,8-tetrachlorodibenzo-p-dioxin and Aroclor 1254 on thyroxine metabolism and transport. Dioxin 93: Proc. 13th Int. Symp. Dioxins Related Compds. 13: 137-140

Lowry, O. H., Rosebrough, N. S., Farr, A. L. and Randall, R. J., (1951) Protein measurement with the folin phenol reagent. J. Biol. Chem. 193: 265 -275

Lu, A. Y. H. and Levin, W. (1972) Partial purification of cytochrome P-450 cytochrome P488 from rat liver microsomes. Biochem. Biophys. Res. Commun. 46: 1344-1339

McClain, R. M., (1989) The significance of hepatic microsomal enzyme induction and altered function in rats: implications for thyroid gland neoplasia. Toxicol. Pathol. 17: 294306

McClain, R. M., Levin, A. A., Posch, R. and Downing, J. C. (1989) The effect of phenobarbital on the metabolism and excretion of thyroxin in rats. Toxicol. Appl. Pharmacol. 99: 216-228

Muller, G. J., Coughtrie, W. H. and Burchell, B. (1990) Conjugation reactions in drug metabolism. 51-105, Tatlor \& Francis, London

National Toxicology Program (NTP) (1982) Bioassay of 2,3,7,8-tetrachloro-dibenzo-pdioxin for possible carcinogenicity (Gavage study). Technical Report Series No. 102, Research Triangle Park, NC

Porterfield, S. P. and Hendrich, C. E. (1993) The role of thyroid hormones in perinatal and neonatal neurological development current perspectives. Endocrinol. Rev. 14 : $94-$ 106

Reddy, B. S., Rao, C. V., Rivenson, A and Kelloff, G. (1993) Chemo-prevention of colon carcinogenesis by organosulfur compounds. Cancer Res. 53: 3493-3498

Ruiz de Ona, C., Obregon, M. J., Escobar del Rey, F. and Morreal de Escobar, G. (1988) Developmental changes in rat brain 5 ' deiodinase and thyroid hormones during the fetal period: The effects of fetal hypothyroidism and maternal thyroid hormones. Pediatr. Res. 24: 588-594

Sparnins, V. L., Barany, G. and Wattenberg, L. W. (1988) Effects of organosulfur compounds from garlic and onions and benzo(a)pyrene-induced neoplasia and glutathione S-transferase activity in the mouse. Carcinogenesis 9: 131-134

Sumiyoshi. H. and Wargovich, M. J. (1990) Chemoprevention of 1,2-dimethylhydrazineinduced colon cancer in mice by naturally occuring organosulfur compounds. Cancer Res. 50: 5084-5087

Takada. N., Matsuda. T., Konishi. Y. and Fukushima. S. (1994) Enhance-ment by organosulfur compounds from garlic and onions of diethylnitro-samine induced glutathione-S-transferase positive foci in the rat liver. Cancer Res. 54: 2895-2899 
Takahashi, S., Hakoi, K., Yada, H., Hirose, M., Ito, N. and Fukushima, S. (1992) Enhancing effects of diallyl sulfide on hepatocarcinogenesis and inhibitory actions of the related diallyl disulfide on colon and renal carcino-genesis in rats. Carcinogenesis 13 1513-1518

Talalay, P. (1992) The role of enzyme induction against carcinogenesis. In Cancer Chemoprevention (Wattenberg, L. W., Lipkin, M., Boone, C. W. and Kelloff, G. J., eds.), pp. 469-478, CRC Press, Boca Raton

Tephly. T.R and Burchell. B. (1990) UDP-Glucuronosyltransferase: a family of detoxifying enzymes. Trends Pharmacol. Sci. 11: 276-279

Van Birgelen, A. P. J., Smit, A. E., Bol. I., Fase, C. M., Van den Berg, M. and Brouwer, A. (1993) Subchronic effects of 2,3,3',4,4'5-hexachlorobi-phenyl or 2,3,7,8tetrachlorodibenzo-p-dioxin in thyroid hormone and retinoid metabolism-possible role of cytochrome P450 and UDP-glucuro-nosyltransferase. Dioxin 93; Proc. 13th Int. Symp. Dioxins Related Compds. 13: 141-144

Van Birgelen, A. P. J. M., van der Kolk, J., Fase, K. M., Bol. I., Poiger, H., Van den Berg, M. and Brouwer, A. (1994) Toxic potency of 2,3,3',4,4',5-hexachlorobiphenyl relative to and in combination with 2,3,7,8-tetrachloro-dibenzo-p-dioxin in a subchronic feeding study in the rat. Toxicol. Appl. Pharmacol. 126: 202-213

Visser, T. J., Kaptein, E., Van Toor, H., Van Raaij, J. A. G. M., van den Berg, K. J. Tjinog Tjin Joe, C., van Eongelen, J. G. M., and Brouwer, A. (1993) Glucuronidation of thyroid hormone in rat liver: effects of in vivo treatment with microsomal inducers and in vitro assay conditions. Endocrinology 133: 2177-2186

Wargovich, M. J. (1987) Diallyl sulfide, a flavor component of garlic (Allium Sativum), inhibits dimethylhydrazin-induced colon cancer. Carcinogenesis 8:487-489

Wargovich, M. J., Woods, C., Eng, V. W. S., Stephens, L. C. and Gray, K. (1988) Chemoprevention of $\mathrm{N}$-nitrosomethylbenzylamine-induced esophageal cancer in rats by the naturally occurring thioether diallyl sulfide. Cancer Res. 48: 6872-6875
Wargovich, M. J., Imado, O, and Stephens, L. C. (1992) Initiation and postinitiation chemopreventive effects of diallyl sulfide in esophageal carcinogenesis, Cancer Lett. 64: $39-42$

Wattenberg. L. W., Sparnins, V. L. and Barany, G. (1989) Inhibition of nitrosodiethyl amine carcinogenesis in mice by naturally occurring organosulfur compounds and monoterpenes. Cancer Res. 49: 2689-2692

Wattenberg, L. W. (1992) Chemoprevention of cancer by naturally occurring and synthetic compounds. In Cancer Chemoprevention (Wattenberg, L. W., Lipkin, M., Boone, C. W. and Kelloff, G. J., eds.), pp. 19-39, CRC Press, Boca Raton 